\title{
Marker-assisted Selection for Combining Resistance to Bacterial Spot and Bacterial Speck in Tomato
}

\author{
Wencai Yang and David M. Francis ${ }^{1}$ \\ Department of Horticulture and Crop Science, The Ohio State University, Ohio Agricultural Research \\ and Development Center, 1680 Madison Avenue, Wooster, OH 44691
}

\begin{abstract}
AdDITIONAL INDEX words. Xanthomonas euvesicatoria, X. vesicatoria, X. perforans, X. gardneri, Pseudomonas syringae pv. tomato, plant breeding, DNA isolation method

Aвstract. The lack of resistance to bacterial diseases increases both the financial cost and environmental impact of tomato (Lycopersicon esculentum Mill.) production while reducing yield and quality. Because several bacterial diseases can be present in the same field, developing varieties with resistance to multiple diseases is a desirable goal. Bacterial spot (caused by four Xanthomonas Dowson species) and bacterial speck (caused by Pseudomonas syringae pv. tomato Young, Dye and Wilkie) are two economically important diseases of tomato with a worldwide distribution. The resistance gene Pto confers a hypersensitive response (HR) to race 0 strains of the bacterial speck pathogen. The locus $R x 3$ explains up to $41 \%$ of the variation for resistance to bacterial spot race $\mathrm{T} 1$ in field trials, and is associated with HR following infiltration. Both Pto and Rx3 are linked in repulsion phase on chromosome 5. We made a cross between two elite breeding lines, Ohio 981205 carrying Pto and Ohio 9834 carrying $R x 3$, to develop an $F_{2}$ population and subsequent inbred generations. Marker-assisted selection (MAS) was applied to the $F_{2}$ progeny and to $F_{2: 3}$ families in order to select for coupling-phase resistance. Thirteen homozygous progeny from $419 \mathrm{~F}_{2}$ plants and 20 homozygous families from $3716 F_{3}$ plants were obtained. Resistance was confirmed in all selected families based on HR in greenhouse screens using bacterial speck race 0 and bacterial spot race $\mathrm{T} 1$ isolates. Resistance to bacterial spot race T1 was confirmed in the field for 33 of the selected families. All selected families were also resistant to bacterial speck in the field. MAS was an efficient tool to select for desirable recombination events and pyramid resistance.
\end{abstract}

Bacterial spot of tomato is a disease complex with five races, T1 to T5, described (Jones et al., 2000, 2004a). It is caused by as many as four species of bacteria [Xanthomonas euvesicatoria ex Doidge, $X$. vesicatoria ex Doidge, $X$. perforans Jones et al.), and X. gardneri Šutic (Doidge, 1921; Jones et al., 2004b; Šutic, 1957)] with taxonomic divisions modified from Vauterin et al. (1995) as described by Jones et al. (2004b). Bacterial spot of tomato occurs throughout the world wherever tomatoes are grown and environmental conditions are favorable for disease development (Stall, 1995). Bacterial spot affects leaves, stems and fruits, and causes both yield and fruit grade losses through defoliation and fruit lesions (Scott, 1997). The resistance to bacterial spot is incompletely or quantitatively inherited.

Bacterial speck of tomato, caused by Pseudomonas syringae pv. tomato, mainly occurs on foliage and fruit, and causes yield loss in field and greenhouse grown tomatoes. Two races, 0 and 1, have been reported to date (Scott, 1997). Genetic studies indicated that single dominant genes control resistance to bacterial speck. Four genes, Pto-1 to Pto-4, have been reported (Pilowsky and Zutra, 1986; Pitblado and MacNeill, 1983; Stockinger and Walling, 1994; Tanksley et al., 1996). Pto-1 is also generally referred to as Pto and has been cloned (Martin et al., 1993). The resistance gene Pto is widely deployed in both fresh market and processing tomato varieties.

\footnotetext{
Received for publication 13 Dec. 2004. Accepted for publication 4 Apr. 2005. The authors thank Troy Aldrich for his assistance with greenhouse and field experiments. Salaries and research support were provided by state and federal funds appropriated to The Ohio State Univ., Ohio Agricultural Research and Development Center, and grant funds from the Mid-American Food Processors. The mention of firm names or trade products does not imply that they are endorsed or recommended by The Ohio State Univ. over other firms or similar products not mentioned.

1To whom reprint requests should be addressed. E-mail: francis.77@osu.edu
}

The lack of resistance to bacterial spot in tomato varieties leads to frequent application of copper sprays and the failure of growers to adopt disease forecasting tools that minimize control sprays for fungal pathogens. Disease forecasting models for tomato do not predict bacterial infection and growers default to a calendar application of copper and fungicide tank mixes. The lack of resistance to bacterial diseases therefore adds to the cost of production beyond loss of yield and quality and results in the use of more pesticides than are necessary to control fungal diseases. Although the development of varieties with resistance to multiple bacterial diseases is a desirable goal, the process has been difficult due to the necessity of selecting for multiple diseases and the emergence of new species and races.

Marker-assisted selection (MAS) offers an opportunity to circumvent some of the problems associated with phenotypic selection for resistance to multiple bacterial pathogens and races. MAS has been successfully used to select for single qualitative or quantitative traits in many crops. These include the extensive use of an acid phosphatase isozyme polymorphism to select for root-knot nematode (Meloidogyne spp.) resistance in tomato (Carboni et al., 1995; Medina-Filho and Stevens, 1980; Rick and Fobes, 1974). Other applications of MAS to disease and pest resistance breeding include Potato Virus Y in Solanum tuberosum L. (Hamalainen et al., 1997); southwestern corn borer (Diatraea grandiosella Dyar) in Zea mays L. (Willcox et al., 2002); and downy mildew [Plasmopara halstedii (Farl.) Berl. et de Toni] on Helianthus annuus L. (Brahm et al., 2000). Markers have been used to combine multiple genes for rust [Uromyces appendiculatus (Pers.) Unger] resistance in Phaseolus vulgaris L. (Kelly et al., 1993) and bacterial blight [Xanthomonas oryzae pv. oryzae (Ishiyama) Swings] resistance genes in Oryza sativa L. (Huang et al., 1997; Yoshimura et al., 1995). Quality traits that have been manipulated through MAS include high-molecular-weight glutenin in Triticum aestivum L. (Ahmad, 2000); the waxy genes 
in O. sativa (Ramalingam et al., 2002); seed size in Glycine max (L.) Merr. (Hoeck et al., 2003); and fiber strength in Gossypium hirsutum L. (Zhang et al., 2003). The potential for combining resistance and quality traits makes MAS an appealing strategy for increasing the efficiency of plant breeding.

A previous study indicated that three quantitative trait loci (QTL) in Hawaii 7998 confer a hypersensitive response (HR) to race T1 of bacterial spot (Yu et al., 1995). $R x 1$ and $R x 2$ are located on the top and bottom of chromosome 1, respectively, and $R x 3$ is located on chromosome 5. Only the Rx3 locus has been demonstrated to provide resistance in the field against T1 strains, and it explains as much as $41 \%$ of the variation for resistance (Yang et al., 2005). Both Pto and Rx3 are located on chromosome 5, but are derived from different sources and the linkage of desirable alleles is therefore in repulsion phase. The use of phenotypic selection to combine resistance is complicated by the need to identify recombinant plants, to distinguish recombinants from plants that are heterozygous for alleles from both parents, and to select for homozygous resistance in coupling phase. Selection based on markers allows for efficient classification while reducing the resources necessary for phenotypic evaluation. The objective of this study was to use MAS to select coupling phase recombinants in order to develop lines with resistance to both diseases.

\section{Materials and Methods}

Plant material. Two inbred backcross lines (IBLs) were used to pyramid the resistance gene, Pto, and the locus, Rx3. Ohio 9834 is an IBL derived from Hawaii 7998 and Ohio 88119 carrying the $R x 3$ locus for partial resistance to race $\mathrm{T} 1$ of bacterial spot (Francis and Miller, 2004; Yang et al., 2005) but no resistance to bacterial speck. Ohio 981205 is an IBL in the Ohio 88119 genetic background carrying $P$ to for resistance to race 0 of bacterial speck but no resistance to bacterial spot. The Ohio 88119 genetic background was chosen due to its concentrated early set and use as an elite line in commercial tomato hybrids (Berry et al., 1995; Francis et al., 2002). A cross was made between Ohio 9834 and Ohio 981205 to develop an $F_{2}$ population and subsequent inbred generations.

Individual $\mathrm{F}_{2}$ plants were grown in 288 Square Plug Tray Deep (Landmark Plastic Corp., Akron, Ohio) with PRO-MIX (Premier Brands, Yonkers, N.Y.) in the greenhouse for DNA isolation and selection. Selected $\mathrm{F}_{2}$ plants were transplanted into 7.6-L pots, allowed to set fruit, and seeds were collected. Seed from selected $\mathrm{F}_{2: 3}$ families was again sown in 288 cell trays, and homozygous individuals were selected from heterozygous families prior to transplant into the field.

DNA ISOLATION AND MARKER ANALYSIS. Genomic DNA was isolated from fresh young leaves 96 samples at a time. To prevent

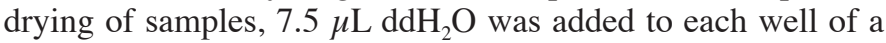
flat-bottom 96-well plate (96-APF-1CO; Rainin Instrument Co., Woburn, Mass.) and the plate was kept on ice. A leaf disk from each individual plant was collected using a hole punch. After all tissue samples were collected, $100 \mu \mathrm{L}$ of $0.25 \mathrm{~N} \mathrm{NaOH}$ was added to each well and the leaf disks were ground 3-5 min using a 96-prong seed crusher (PerkinElmer, Norton, Ohio). Following grinding, a $7.5-\mu \mathrm{L}$ aliquot of each extract was transferred to a 96-well plate containing $75 \mu \mathrm{L}$ of ice-cold neutralization solution (0.05 м Tris- $\mathrm{HCl} \mathrm{pH} 7.0,0.1 \mathrm{~mm}$ EDTA) in each well. The neutralized solution is ready for use as DNA template in PCR applications and can be stored at $-20{ }^{\circ} \mathrm{C}$ for at least 1 month.
Two PCR-based DNA markers were used to genotype individuals. Marker Pto (forward primer: 5'-ATCTACCCACAATGAGCATGAGCTG-3', reverse primer: 5'-GTGCATACTCCAGTTTCCAC-3') was designed according to the sequence of the cloned gene Pto (Coaker and Francis, 2004; Martin et al., 1993). Of three markers (TOM49, Rx3-L1, and CosOH73) linked to the $R \times 3$ locus, marker Rx3-L1 (forward primer: 5'CTCCGAGCGAAGAGTCTAGAGTC-3', reverse primer: 5'GAAGGCAAAAGGAAAAGGAGAAGGATGG-3’) explains the highest phenotypic variation (Yang et al., 2005) and therefore was used for selection. PCR reactions were conducted in a $20-\mu \mathrm{L}$ volume consisting of $10 \mathrm{~mm}$ Tris- $\mathrm{HCl}$ ( $\mathrm{pH} 9.0$ at room temperature), $50 \mathrm{~mm} \mathrm{KCl}, 1.5 \mathrm{~mm} \mathrm{MgCl}_{2}, 50 \mu \mathrm{M}$ of each dNTP, $0.3 \mu \mathrm{m}$ primers, $2 \mu \mathrm{L}$ genomic DNA template and 1 unit of Taq DNA ploymerase. Reactions were heated at $94^{\circ} \mathrm{C}$ for $2 \mathrm{~min}$ followed by 36 cycles of $1 \mathrm{~min}$ at $94^{\circ} \mathrm{C}, 1 \mathrm{~min}$ at $60^{\circ} \mathrm{C}$, and a 2 -min extension at $72^{\circ} \mathrm{C}$. Final reactions were extended at $72^{\circ} \mathrm{C}$ for $5 \mathrm{~min}$. Amplification was performed in a programmable thermal controller (PTC-100; MJ Research, Watertown, Mass.). Polymorphisms were detected as cut amplified polymorphisms (CAP). The PCR products were digested with Rs $\mathrm{I}$ for Pto and BsrB I for Rx3-L1 according to the enzyme manufacturers' protocols. Fragments were separated using 2\% agarose gels (Biotechnology Grade 3:1 agarose; Amresco, Solon, Ohio), stained with ethidium bromide, and photographed using the Syngene BioImaging System (Cambridge, U.K.).

Recombination between markers was estimated using maximum-likelihood (Allard, 1956).

GREENHOUSE AND FIELD EXPERIMENTS. Areplicated randomized complete-block design was used for greenhouse disease evaluation. Ohio 88119 was used as a susceptible control for both diseases, Ohio 9834 was used as a resistant control for bacterial spot race T1, and Ohio 981205 was used as a resistant control for bacterial speck race 0 . In the greenhouse, five $\mathrm{F}_{3: 4}$ plants of each selected family and controls were grown in each of two blocks using PRO-MIX with fertilizer and water supplied as needed. Two strains, $X c v 89$ and $X c v 110 \mathrm{c}$, of bacterial spot race T1 and one strain, DC3000, of bacterial speck race 0 were used for infiltration. The inoculum concentration was adjusted to $\approx 2 \times$ $10^{8} \mathrm{cfu} / \mathrm{mL}$ for strains $X c v 89$ and $X c v 110 \mathrm{c}$, and $4 \times 10^{7} \mathrm{cfu} / \mathrm{mL}$ for strain DC3000. The plants were misted with water $1 \mathrm{~h}$ before inoculation. The inoculum was infiltrated through the back of a fully expanded leaflet on the third true leaf using a 3-mL syringe without needle when plants were at the fourth true-leaf stage. The inoculated plants were kept at $20-25^{\circ} \mathrm{C}$ in a humid environment. HR was recorded 24-72 $\mathrm{h}$ after inoculation.

In the field, 20 plants of each selected $\mathrm{F}_{2: 3}, \mathrm{~F}_{3: 4,}$ and controls were grown in each of two blocks at The Ohio State Univ.'s Vegetable Crops Branch in Fremont, Ohio, using conventional practices (Precheur, 2000) in 2002 and 2003. In 2002, the plants were inoculated with a T1 strain of bacterial spot and the disease was scored using 1-12 scale as described previously (Horsfall and Barratt, 1945; Scott et al., 1995). Early blight [Alternaria solani (Ell. \& Mart.) Jones \& Grout] naturally occurred and spread in the field in 2002, this disease was also scored using the same scale. Early blight and bacterial spot were distinguished based on characteristics of the lesions as follows: concentric rings are present in early blight lesions in contrast to black lesions found in bacterial spot infected plants; early blight lesions are surrounded by a yellow hallow in contrast to the absence of a halo or a light green halo found surrounding bacterial spot lesions. In 2003, the field was naturally infected by bacterial speck. The reactions of plants to this disease were recorded as resistant or susceptible. 
Statistical analysis. Analysis of variance (ANOVA) and mean separations were performed using the General Liner Model procedure of SAS (version 8.1; SAS Institute, Cary, N.C.). Mean separations were based on the least significant difference (LSD) after a significant $\mathrm{F}$ test in the ANOVA. Genotype was considered as a fixed-effect variable, while block was considered as a random-effect variable.

\section{Results}

Selection of COUPLing PHASE Recombinants USING DNA MARKERS. A total of $419 \mathrm{~F}_{2}$ plants were subject to DNA marker analysis for two CAP markers, Pto and Rx3-L1. Primers for marker Pto amplified a 552-base pair (bp) fragment from both resistant and susceptible parents. The restriction enzyme Rsa I did not cut the PCR product from the resistant parent Ohio 981205 , but cut the PCR product from the susceptible parent Ohio 9834 into two fragments, $113 \mathrm{bp}$ and $439 \mathrm{bp}$ (Fig. 1A). Primers for marker Rx3-L1 amplified a 323-bp fragment from both resistant and susceptible parents. The restriction enzyme $B s r \mathrm{~B}$ I did not cut the PCR product from the bacterial spot susceptible parent Ohio 981205, but digested the PCR product from the resistant parent Ohio 9834 into two fragments, 275 and 48 bp (Fig. 1B). Both markers are co-dominant. The segregation ratio for both markers in the population was consistent with the expected 1:2:1 ratio at $P=0.05\left(\chi^{2}=1.57\right.$ for Pto, $\chi^{2}=5.77$ for Rx3-L1).

Based on marker genotypes, $13 \mathrm{~F}_{2}$ plants were homozygous for desirable recombination events, and thus represent the fusion of two recombinant gametes. These $13 \mathrm{~F}_{2}$ individuals were transplanted and grown in the greenhouse as a source of $\mathrm{F}_{2: 3}$ seed for field evaluation. A further 94 families were heterozygous for desirable recombination events. The estimate of recombination between markers was $36.8 \pm 2.2 \mathrm{~cm}$ for this cross. To obtain a
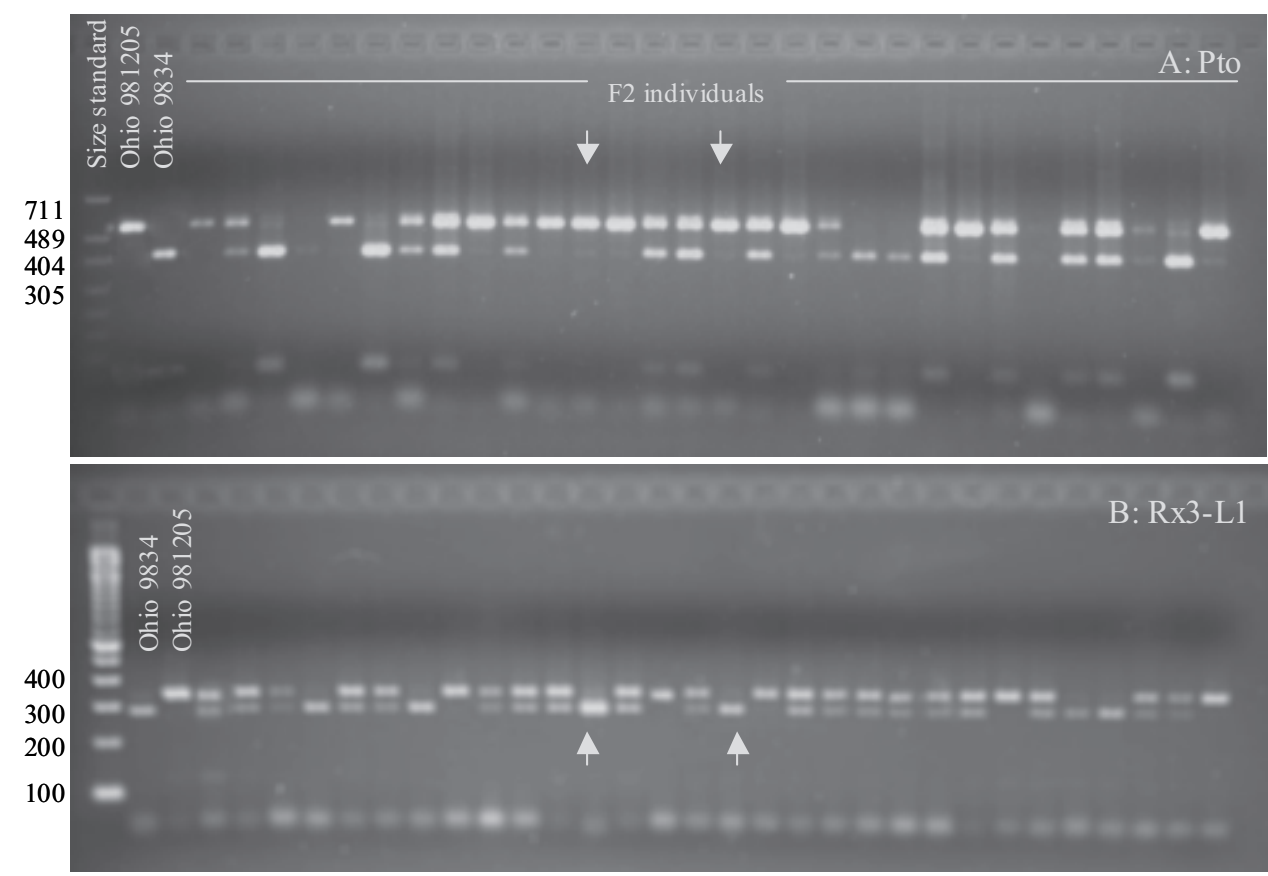

Fig. 1. Molecular marker banding patterns for tomato parental lines, Ohio 981205 and Ohio 9834 , and $F_{2}$ progeny. For the marker Pto (A), fragment sizes are 552 bp for the Ohio 981205 allele (resistant) and 113 bp and 439 bp for the Ohio 9834 allele (susceptible). Fragment sizes for marker Rx3-L1 (B) are 323 bp for the bacterial spot susceptible parent, Ohio 981205 , and 275 bp and 48 bp for the resistant parent, Ohio 9834. Recombinant individuals with resistance in coupling phase are indicated by arrows. larger population of plants homozygous for desirable coupling phase recombination events, $20 \mathrm{~F}_{2}$ individuals heterozygous for favorable recombination events were randomly selected and grown in the greenhouse to develop $\mathrm{F}_{2: 3}$ families. A total of 3176 plants in the $20 \mathrm{~F}_{2: 3}$ families were genotyped and homozygous recombinant plants were transplanted to the field. At least 40 homozygotes were selected for each family and randomly divided between two plots in the field.

HyPERSENSITIVE RESPONSE IN THE PARENTAL GENOTYPES AND SELECTED FAMILIES. Seed was saved from individual $F_{3}$ plants in the field and $F_{3: 4}$ plants from each selection were used for greenhouse evaluation of resistance. Five plants from each family were infiltrated with strain DC3000 for bacterial speck race 0 and strains $X c v 89$ and $X c v 110 c$ for bacterial spot race T1. For bacterial speck, all selected plants and Ohio 981205 showed HR within $24 \mathrm{~h}$. For bacterial spot, however, HR was unambiguous 48-72 $\mathrm{h}$ after infiltration in the selected families. The susceptible control Ohio 88119 and line Ohio 981205 showed water-soaked disease lesions $5 \mathrm{~d}$ after infiltration. Hawaii 7998 showed HR within $24 \mathrm{~h}$ and Ohio $9834(R \times 3)$ showed HR $48 \mathrm{~h}$ after infiltration, with a reaction that was quantitatively distinct from the reaction of Hawaii 7998. It is not clear what caused the delay in HR in Ohio 9834 and selected lines, though it is clear that resistance in Hawaii 7998 is conferred by genes in addition to $R x 3$ (Yang et al., 2005; Yu et al., 1995).

Performance of SElected families for disease Resistance IN THE FIELD. Although we confirmed HR to race T1 strains in the selected families, the relationship between HR and resistance in the field is not well established. Somodi et al. (1996) found the correlation between HR and field susceptibility was $r=0.31$. For this reason we chose to verify resistance under field conditions. The 33 selected $F_{2 \cdot 3}$ families and three controls, Ohio 88119, Ohio 9834, and Ohio 981205, were grown in a replicated trial inoculated with race T1 strains of bacterial spot. The susceptible controls, Ohio 88119 and Ohio 981205 , had high disease ratings, whereas the resistant line Ohio 9834 had a relatively low rating. All selected families had significantly lower disease ratings than the susceptible controls (Table 1). Only one family (SG01-3002) had a disease rating that was significantly higher than Ohio 9834. All other families had equal or lower disease ratings than Ohio 9834. Seventeen of the families had significantly lower disease ratings than Ohio 9834 (Table 1).

Due to the natural occurrence and spread of early blight in 2002, the severity of this disease was also scored. All families showed partial resistance in the field relative to susceptible controls (Table 1). The correlation between resistance to bacterial spot and early blight was significant, but low $(r=0.59, P<0.0001)$. The close agreement between greenhouse results and field performance suggest that the presence of early blight did not confound our assessment of bacterial spot resistance (Table 1). 
Table 1. Response of tomato lines to bacterial speck and bacterial spot based on hypersensitive reaction in the greenhouse and resistance in the field.

\begin{tabular}{|c|c|c|c|c|c|}
\hline \multirow[b]{2}{*}{ Genotype } & \multicolumn{2}{|c|}{ Greenhouse ratingz } & \multicolumn{3}{|c|}{ Field rating } \\
\hline & $\begin{array}{c}\text { Bacterial } \\
\text { speck }\end{array}$ & $\begin{array}{c}\text { Bacterial } \\
\text { spot }\end{array}$ & $\begin{array}{c}\text { Bacterial } \\
\text { speck }^{y}\end{array}$ & $\begin{array}{c}\text { Bacterial } \\
\text { spot }^{x}\end{array}$ & $\begin{array}{l}\text { Early } \\
\text { blightw }^{w}\end{array}$ \\
\hline SG01-3000 & HR & HR & $\mathrm{R}$ & $4.00 \mathrm{a}$ & $4.00 \mathrm{ab}$ \\
\hline SG01-3034 & HR & HR & $\mathrm{R}$ & $4.00 \mathrm{a}$ & $3.50 \mathrm{a}$ \\
\hline SG01-3011 & HR & HR & $\mathrm{R}$ & $4.25 \mathrm{ab}$ & $4.50 \mathrm{a}-\mathrm{c}$ \\
\hline SG01-3004 & HR & HR & $\mathrm{R}$ & $4.50 \mathrm{a}-\mathrm{c}$ & $4.50 \mathrm{a}-\mathrm{c}$ \\
\hline SG01-3008 & HR & HR & $\mathrm{R}$ & $4.50 \mathrm{a}-\mathrm{c}$ & $5.00 \mathrm{a}-\mathrm{d}$ \\
\hline SG01-3023 & HR & HR & $\mathrm{R}$ & $4.75 \mathrm{a}-\mathrm{d}$ & $6.00 \mathrm{c}-\mathrm{e}$ \\
\hline SG01-3028 & HR & HR & $\mathrm{R}$ & $4.75 \mathrm{a}-\mathrm{d}$ & $4.50 \mathrm{a}-\mathrm{c}$ \\
\hline SG01-3003 & HR & HR & $\mathrm{R}$ & $5.00 \mathrm{a}-\mathrm{e}$ & $4.50 \mathrm{a}-\mathrm{c}$ \\
\hline SG01-3010 & HR & HR & $\mathrm{R}$ & $5.00 \mathrm{a}-\mathrm{e}$ & $6.00 \mathrm{c}-\mathrm{e}$ \\
\hline SG01-3015 & HR & HR & $\mathrm{R}$ & $5.00 \mathrm{a}-\mathrm{e}$ & $7.00 \mathrm{e}$ \\
\hline SG01-3020 & HR & HR & $\mathrm{R}$ & $5.00 \mathrm{a}-\mathrm{e}$ & $4.50 \mathrm{a}-\mathrm{c}$ \\
\hline SG01-3022 & HR & HR & $\mathrm{R}$ & $5.00 \mathrm{a}-\mathrm{e}$ & $4.50 \mathrm{a}-\mathrm{c}$ \\
\hline SG01-3029 & HR & HR & $\mathrm{R}$ & $5.00 \mathrm{a}-\mathrm{e}$ & $5.50 \mathrm{~b}-\mathrm{e}$ \\
\hline SG01-3006 & HR & HR & - & $5.25 \mathrm{~b}-\mathrm{f}$ & $5.00 \mathrm{a}-\mathrm{d}$ \\
\hline SG01-3021 & HR & HR & - & $5.25 \mathrm{~b}-\mathrm{f}$ & $4.50 \mathrm{a}-\mathrm{c}$ \\
\hline SG01-3030 & HR & HR & - & $5.25 \mathrm{~b}-\mathrm{f}$ & $5.50 \mathrm{~b}-\mathrm{e}$ \\
\hline SG01-3032 & HR & HR & - & $5.25 \mathrm{~b}-\mathrm{f}$ & $5.00 \mathrm{a}-\mathrm{d}$ \\
\hline SG01-3013 & HR & HR & - & $5.50 \mathrm{c}-\mathrm{f}$ & $4.50 \mathrm{a}-\mathrm{c}$ \\
\hline SG01-3001 & HR & HR & - & $5.75 \mathrm{~d}-\mathrm{g}$ & $5.50 \mathrm{~b}-\mathrm{e}$ \\
\hline SG01-3005 & HR & HR & - & $5.75 \mathrm{~d}-\mathrm{g}$ & $5.00 \mathrm{a}-\mathrm{d}$ \\
\hline SG01-3027 & HR & HR & - & $5.75 \mathrm{~d}-\mathrm{g}$ & $6.00 \mathrm{c}-\mathrm{e}$ \\
\hline SG01-3014 & HR & HR & - & $6.00 \mathrm{e}-\mathrm{g}$ & $6.50 \mathrm{de}$ \\
\hline SG01-3016 & HR & HR & - & $6.00 \mathrm{e}-\mathrm{g}$ & $6.00 \mathrm{c}-\mathrm{e}$ \\
\hline SG01-3017 & HR & HR & - & $6.00 \mathrm{e}-\mathrm{g}$ & $6.50 \mathrm{de}$ \\
\hline SG01-3018 & HR & HR & - & $6.00 \mathrm{e}-\mathrm{g}$ & $6.00 \mathrm{c}-\mathrm{e}$ \\
\hline SG01-3019 & HR & HR & - & $6.00 \mathrm{e}-\mathrm{g}$ & $6.50 \mathrm{de}$ \\
\hline SG01-3024 & HR & HR & - & $6.00 \mathrm{e}-\mathrm{g}$ & $6.50 \mathrm{de}$ \\
\hline SG01-3031 & HR & HR & - & $6.00 \mathrm{e}-\mathrm{g}$ & $6.00 \mathrm{c}-\mathrm{e}$ \\
\hline SG01-3025 & HR & HR & - & $6.25 \mathrm{fg}$ & $6.50 \mathrm{de}$ \\
\hline SG01-3035 & HR & HR & - & $6.25 \mathrm{fg}$ & $6.00 \mathrm{c}-\mathrm{e}$ \\
\hline SG01-3012 & HR & HR & - & $6.50 \mathrm{~g}$ & $5.50 \mathrm{~b}-\mathrm{e}$ \\
\hline SG01-3026 & HR & HR & - & $6.50 \mathrm{~g}$ & $5.50 \mathrm{~b}-\mathrm{e}$ \\
\hline SG01-3002 & HR & HR & - & $7.75 \mathrm{~h}$ & $7.00 \mathrm{e}$ \\
\hline Ohio 9834 & S & HR & S & $6.50 \mathrm{~g}$ & $6.00 \mathrm{c}-\mathrm{e}$ \\
\hline Ohio 88119 & S & S & $S$ & $9.00 \mathrm{i}$ & $7.00 \mathrm{e}$ \\
\hline Ohio 981205 & HR & S & $\mathrm{R}$ & $9.00 \mathrm{i}$ & $6.50 \mathrm{de}$ \\
\hline $\begin{array}{l}\text { Mean } \\
5.51\end{array}$ & & & & & 5.67 \\
\hline $\mathrm{LSD}^{\mathrm{v}} 0.05$ & & & & 1.06 & 1.80 \\
\hline LSD 0.3 & & & & 0.59 & 1.01 \\
\hline
\end{tabular}

${ }^{\mathrm{z}} \mathrm{HR}=$ hypersensitive response, $\mathrm{S}=$ susceptible.

yacterial speck resistance was scored qualitatively as $\mathrm{R}=$ resistant or $\mathrm{S}=$ susceptible in the field in 2003. Families that were not evaluated in 2003 are indicated "-".

Bacterial spot ratings were taken in the field in 2002 using a modified Horsfall-Barratt (1945) system in which $1=0 \%, 2=0 \%$ to $3 \%, 3=3 \%$ to $6 \%, 4=6 \%$ to $12 \%, 5=12 \%$ to $25 \%, 6=25 \%$ to $50 \%, 7=50 \%$ to $75 \%, 8=75 \%$ to $87 \%, 9=87 \%$ to $94 \%, 10=94 \%$ to $97 \%, 11=97 \%$ to $100 \%$, and $12=100 \%$ diseased tissue.

wEarly blight ratings followed the scale used for bacterial spot.

vMean separation in columns are based on Duncan's multiple range test at $P \leq 0.05$, least significant difference (LSD) at $P=0.05$ and $P=0.3$.

The selected $13 \mathrm{~F}_{3: 4}$ lines and three controls, Ohio 88119, Ohio 9834, and Ohio 981205, were grown in the field in Fremont, Ohio, in Summer 2003. Facilitated by the cool and humid weather in the early summer, bacterial speck naturally spread in the field. All selected lines and the control Ohio 981205 showed resistance to this infection while Ohio 88119 and Ohio 9834 were susceptible (Table 1).

\section{Discussion}

Breeding for resistance to bacterial spot is difficult due to several factors, including the presence of multiple species and races of the pathogen, the lack of an easy method to screen plants for resistance, and the lack of available disease resistance in commercially acceptable genetic backgrounds. A strategy that alternates MAS with field selection offers an opportunity to select for resistance and horticultural performance. The relative efficiency of MAS in producing gain under selection is one of the major concerns for using DNA markers in a breeding program. MAS may produce high efficiencies compared to phenotypic selection when using a marker that is tightly linked to a qualitative trait, when the selection unit is a single plant rather than a replicated line, and when the proportion of phenotypic variance explained by the marker is high (Francis et al., 2003). In the case of Pto, the target gene is the marker and heritability is expected to approach 1. However, the success of MAS for a QTL is dependent on several factors including linkage distance and the strength of the QTL (Dudley, 1993; Kearsey and Farquhar, 1998). There is a possibility of losing the QTL-marker association when flanking markers are not used (Dudley, 1993; Willcox et al., 2002; Zhou et al., 2003). In this study we applied MAS to the $R \times 3$ locus, a major QTL from Hawaii 7998 that confers field resistance to race $\mathrm{T} 1$ of bacterial spot. Three markers with the order of TOM49, $\mathrm{Rx} 3-\mathrm{L} 1$, and $\mathrm{Cos} \mathrm{OH} 73$ show significant association with resistance. Marker Rx3L1 explains a higher phenotypic variation than the two flanking markers (Yang et al., 2005), and in this study, successfully selected individuals showing resistance in selected families.

Markers Pto and Rx3-L1 were separated by $36.8 \mathrm{~cm}$, and the selected families we tested reacted with an HR when challenged with $\mathrm{T} 1$ strains of the bacterial spot pathogen. This observation suggests that the $R \times 3$ locus is distal to Rx3-L1 or very closely linked in a proximal position, relative to Pto. The distance between loci in centimorgans will be dependent on genetic backgrounds. For example, the estimate of recombination in the Ohio $9834 \mathrm{x}$ Ohio 981205 cross was larger than the $28.8 \mathrm{~cm}$ estimated for the reference L. esculentum $\times$ L. pennellii (Corr.) D'Arcy population (Tanksley et al., 1992), which may be attributed to effects of the wide cross. We have observed recombination distances between Pto and Rx3-L1 as low as 14 см in some crosses (unpublished data). Given this range of recombination, phenotypic selection 
for Pto and $R x 3$ in coupling phase would require the evaluation of $\approx 11$ individuals from between 62 (assuming $r=0.37$ ) and 168 (assuming $r=0.14$ ) $\mathrm{F}_{3}$ families in order to have a $95 \%$ probability of detecting at least one family segregating for individuals that were homozygous resistant for both Pto and $R x 3$. Thus phenotypic selection based on screening a minimum of $680 \mathrm{~F}_{3}$ individuals would be required assuming $37 \mathrm{~cm}$, assuming only half of the recombination events are favorable (resistance in coupling phase), and assuming a $25 \%$ frequency of recovering the favorable homozygous event in $\mathrm{F}_{2: 3}$ individuals (Sedcole, 1977). The ability to identify favorable recombinant events in the heterozygous condition gives MAS an advantage for pyramiding these genes. However, the loose linkage between Pto and Rx3 will require verification of resistance following subsequent crosses.

In the Great Lakes region, multiple bacterial diseases, including bacterial spot, bacterial speck, and bacterial canker [Clavibacter michiganensis ssp. michiganensis (Smith) Davis], occur simultaneously due to high humidity and frequent rains during the tomato-growing season. These diseases cause yield and quality loss and they are difficult to control. Pyramiding resistance from difference sources into a breeding line or hybrid offers a potential strategy to reduce the impact of bacterial disease. We demonstrate the feasibility of combining Pto and $R x 3$ through MAS as a first step in developing varieties with resistance to multiple bacterial diseases. The Rx3 locus is from a poorly adapted L. esculentum line Hawaii 7998 while Pto can be traced back to its origin of PI 370093 (Pitblado and Kerr, 1980). To combine these two unlinked loci required introgression of the resistance loci and selection of favorable coupling phase recombination events. Both processes were facilitated by combining MAS and field selection. Markerassisted selection was of particular use in selecting coupling phase recombination to pyramid Pto with a QTL for resistance to race T1 of bacterial spot. The families developed in this study will be of use in efforts to breed for multiple resistances to bacterial disease.

\section{Literature Cited}

Ahmad, M. 2000. Molecular marker-assisted selection of HMW glutenin alleles related to wheat bread quality by PCR-generated DNA markers. Theor. Applied Genet. 101:892-896.

Allard, R.W. 1956. Formulas and tables to facilitate the calculation of recombination values in heredity. Hilgardia 24:235-278.

Berry, S.Z., T.S.Aldrich, K.L. Wiese, and W.D. Bash. 1995. 'Ohio OX38' hybrid processing tomato. HortScience 30:159.

Brahm, L., T. Rocher, and W. Friedt. 2000. PCR-based markers facilitating marker assisted selection in sunflower for resistance to downy mildew. Crop Sci. 40:676-682.

Carboni,A., G. Grassi, and M. Dicandilo. 1995. PCR selection method for nematode resistance in tomato. Minerva Biotecnologica 7:297-301.

Coaker, G.L. and D.M. Francis. 2004. Mapping, genetic effects, and epistatic interaction of two bacterial canker resistance QTLs from Lycopersicon hirsutum. Theor. Applied Genet. 108:1047-1055.

Doidge, E.M. 1921. A tomato canker. Ann. Appl. Biol. 7:407-430.

Dudley, J.W. 1993. Molecular markers in plant improvement: Manipulation of genes affecting quantitative traits. Crop Sci. 33:660-668.

Francis, D.M., S.Z. Berry, T.S. Aldrich, K.L. Scaife, and W.D. Bash. 2002. 'Ohio OX 150 ' processing tomato. Rpt. Tomato Genet. Coop. 52:36-37.

Francis, D.M., A.R. Miller, Z. Chen, A.M. Bongue Bartelsman, and C.A. Barringer. 2003. State of the art of genetics and breeding of processing tomato: A comparison of selection based on molecular markers, biochemical pathway, and phenotype for the improvement of fruit color and juice viscosity. Acta Hort. 613:273-282.

Francis, D.M. and S. Miller. 2004. Ohio 9834 and Ohio 9816: Processing tomato breeding lines with partial resistance to race $\mathrm{T} 1$ of bacterial spot. Rpt. Tomato Genet. Coop. 54:49.

Hamalainen, J.H., K.N. Watanabe, J.P.T. Valkonen, A. Arihara, R.L. Plaisted, E. Pehu, L, Miller, and S.A. Slack. 1997. Mapping and marker-assisted selection for a gene for extreme resistance to potato virus Y. Theor. Applied Genet. 94:192-197.

Hoeck, J.A., W.R. Fehr, R.C. Shoemaker, G.A. Welke, S.L. Johnson, and S.R. Cianzio. 2003. Molecular marker analysis of seed size in soybean. Crop Sci. 43:68-74.

Horsfall, J.G. and R.W. Barratt. 1945. An improved grading system for measuring plant diseases. Phytopathology 35:655.

Huang, N., E.R. Angeles, J. Domingo, G. Magpantay, S. Singh, G. Zhang, N. Kumaravadivel, J. Bennett, and G.S. Khush. 1997. Pyramiding of bacterial blight resistance genes in rice: Marker-assisted selection using RFLP and PCR. Theor. Applied Genet. 95:313-320.

Jones, J.B., H. Bouzar, R.E. Stall, E.C. Almira, P.D. Roberts, B.W. Bowen, J. Sudberry, P.M. Strickler, and J. Chun. 2000. Systematic analysis of xanthomonads (Xanthomonas spp.) associated with pepper and tomato lesions. Intl. J. Systematic and Evolutionary Microbiology 50:1211-1219.

Jones, J.B., G.H. Lacy, H. Bouzar, G.V. Minsavage, R.E. Stall, and N.W. Schaad. 2004a. Bacterial spot-World wide distribution, importance and review. $1^{\text {st }}$ Intl. Symp. Tomato Dis. and $19^{\text {th }}$ Annu. Tomato Dis. Wkshp. Orlando, Fla., 20-24 June 2004. p. 21.

Jones, J.B., G.H. Lacy, H. Bouzar, R.E. Stall, and N.W. Schaad. 2004b. Reclassification of the xanthomonads associated with bacterial spot disease of tomato and pepper. Systematic and Applied Microbiol. 27:755-762.

Kearsey, M.J. and G.L. Farquhar. 1998. QTL analysis in plants: Where are we now? Heredity 80:137-142.

Kelly J.D., J.R. Stavely, P. Miklas, L. Afanador, and S.D. Haley. 1993. Pyramiding rust resistance genes using RAPD markers. Ann. Rpt. Bean Improvement Coop. 36:166-167.

Martin, G.B., S.H. Brommonschenkel, J. Chunwongse, A. Frary, M.W. Ganal, R. Spivey, T. Wu, E.D. Earle, and S.D. Tanksley. 1993. Mapbased cloning of a protein kinase gene conferring disease resistance in tomato. Science 262:1432-1436.

Medina-Filho, H.P. and M.A. Stevens. 1980. Tomato breeding for nematode rsistance: Survey of resistant varieties for horticultural characteristics and genotype of acid phosphatase. Acta Hort. 100:383-393.

Pilowsky, M. and D. Zutra. 1986. Reaction of different tomato genotypes to the bacterial speck pathogen (Pseudomonas syringae pv. tomato). Phytoparasitica 14:39-42.

Pitblado, R.E. and E.A. Kerr. 1980. Resistance to bacterial speck (Pseudomonas tomato) in tomato. Acta Hort. 100:379-382.

Pitblado, R.E. and B.H. MacNeill. 1983. Genetic basis of resistance to Pseudomonas syringae pv. tomato in field tomatoes. Can. J. Plant Pathol. 5:251-255.

Precheur R.J. 2000. Ohio vegetable production guide. The Ohio State Univ. Coop. Ext., Bul. 672.

Ramalingam, J., H.S. Basharat, and G. Zhang. 2002. STS and microsatellite marker-assisted selection for bacterial blight resistance and waxy genes in rice, Oryza sativa L. Euphytica 127:255-260.

Rick, C. M. and J. Fobes. 1974. Association of an allozyme with nematode resistance. Rpt. Tomato Genet. Coop. 24:25.

Scott, J.W. 1997. Tomato improvement for bacterial disease resistance for the tropics: A contemporary basis and future prospects, p. 117-123. In: Proc. First Intl. Conf. on Processing Tomato/First Intl. Symp. on Tropical Tomato Dis., Recife, Brazil. ASHS Press, Alexandria, Va.

Scott, J.W., J.B. Jones, G.C. Somodi, and R.E. Stall. 1995. Screening tomato accession for resistance to Xanthomonas campestris pv. vesicatoria, race T3. HortScience 30:579-581.

Sedcole, J.R. 1977. Number of plants necessary to recover a trait. Crop Sci. 17:667-668.

Somodi, G.C., J.B. Jones, J.W. Scott, J.F. Wang, and R.E. Stall. 1996. Relationship between the hypersensitive reaction and field resistance to tomato race 1 of Xanthomonas campestris pv. vesicatoria. Plant Dis. 80:1151-1154. 
Stall, R.E. 1995. Xanthomonas campestris pv. vesicatoria, p. 167-181. In: U.S. Singh, K. Kohmoto, and R.P. Singh (eds.). Pathogenesis and host specificity in plant diseases: Histopathological, biochemical, genetic and molecular basis. vol. I. Pergamon, Oxford, U.K.

Stockinger, E.J. and L.L. Walling. 1994. Pto-3 and Pto-4: Novel genes from Lycopersicon hirsutum var. glabratum that confer resistance to Pseudomonas syringae pv. tomato. Theor. Applied Genet. 89:879-884.

Šutic, D. 1957. Bakterioze crvenog patlidzana (tomato bacteriosis). Rev. Appl. Mycol. 36:734-735.

Tanksley, S.D., S. Brommonschenkel, and G. Martin. 1996. Pto ${ }^{h}$, an allele of Pto conferring resistance to Pseudomonas syringae pv. tomato (race 0 ) that is not associated with fenthion sensitivity. Rpt. Tomato Genet. Coop. 46:28-29.

Tanksley S.D., M.W. Ganal, J.P. Prince, M.C. Devicente, M.W. Bonierbale, P. Broun, T.M. Fulton, J.J. Giovannoni, S. Grandillo, G.B. Martin, R. Messeguer, J.C. Miller, L. Miller, A.H. Paterson, O. Pineda, M.S. Roder, R.A. Wing, W. Wu, and N.D. Young. 1992. High-density molecular linkage maps of the tomato and potato genomes. Genetics 132:1141-1160.

Vauterin, L., B. Hoste, K. Kersters, and J. Swings. 1995. Reclassification of Xanthomonas. Intl. J. Syst. Bacteriol. 45:472-489.

Willcox, M.C., M.M. Khairallah, D. Bergvinson, J. Crossa, J.A. Deutsch,
G.O. Edmeades, D. Gonzalez-de-Leon, C. Jiang, D.C. Jewell, J.A. Mihm, W.P. Williams, and D. Hoisington. 2002. Selection for resistance to southwestern corn borer using marker-assisted and conventional backcrossing. Crop Sci. 42:1516-1528.

Yang, W., E. Sacks, M.L.L. Ivey, S.A. Miller, and D.M. Francis. 2005. Resistance in Lycopersicon esculentum intraspecific crosses to race T1 strains of Xanthomonas campestris pv. vesicatoria causing bacterial spot of tomato. Phytopathology (In Press).

Yoshimura, S., A. Yoshimura, N. Iwata, S.R. McCouch, M.L. Abenes, M.R. Baraoidan, T.W. Mew, and R.J. Nelson. 1995. Tagging and combining bacterial blight resistance genes in rice using RAPD and RFLP markers. Mol. Breeding 1:375-387.

Yu, Z.H., J.F. Wang, R.E. Stall, and C.E. Vallejos. 1995. Genomic localization of tomato genes that control a hypersensitive reaction to Xanthomonas campestris pv. vesicatoria (Doidge) Dye. Genetics 141:675-682.

Zhang, T.Z., Y.L. Yuan, J. Yu, W.Z. Guo, and R.J. Kohel. 2003. Molecular tagging of a major QTL for fiber strength in upland cotton and its marker-assisted selection. Theor. Applied Genet. 106:262-268.

Zhou, W.C., F.L. Kolb, G.H. Bai, L.L. Domier, L.K. Boze, and N.J. Smith. 2003. Validation of a major QTL for scab resistance with SSR markers and use of marker-assisted selection in wheat. Plant Breeding 122:40-46. 